\title{
The Use of Borehole Breakout for Geotechnical Investigation of an Open Pit Mine
}

\author{
M.J. Fowler Pells Sullivan and Meynink Pty Ltd, Australia \\ F.M. Weir Pells Sullivan and Meynink Pty Ltd, Australia
}

\begin{abstract}
This paper presents the methodology and results of a borehole breakout study using acoustic televiewer borehole images (ATV) as part of the geotechnical investigations at Olympic Dam mine in South Australia.

ATV logging of boreholes is rapidly becoming a standard investigation tool for geological and geotechnical investigations. It is primarily being used to provide high quality structural orientation data. However, the ability to observe and measure borehole breakout provides information on in situ stress and is another benefit of this technique.

This study located 154 cases of breakout in 38 of the 96 holes reviewed. The measurements are presented and compared with conventional stress testing from the existing underground operation comprising CSIRO HI-Cell and Acoustic Emission.

This study presents a summary of the stress condition at Olympic Dam. Clear stress domains are apparent with perturbation adjacent to a known major structure that transects the deposit. The study demonstrates the reliability of borehole breakout as a means of estimating the stress field orientation and its usefulness in augmenting smaller data sets of conventional methods.
\end{abstract}

\section{Introduction}

The Olympic Dam deposit is located $12 \mathrm{~km}$ from the township of Roxby Downs in South Australia (Figure 1). The northern linear part of the deposit has been the focus of underground workings since the mid 1980s and is still in production today. Recent exploration of the southern part of the ore body is aimed at expansion of the project to include a large open pit mine. These investigations have provided the data for this study.

The geological investigations of the southern portion of the ore body are primarily comprised of $800 \mathrm{~m}$ deep diamond cored drill holes. Traditional core logging of these holes has been complimented by the use of down hole acoustic imaging tools (Acoustic Televiewer). The primary purpose of the acoustic imaging was to provide high accuracy orientation data on structural features identified in boreholes. This imaging also enabled the detection of stress-induced failure (borehole breakout or tensile fracturing) of the borehole wall. Borehole breakout has commonly been used to assess the in situ stress condition, particularly the direction of the maximum principal horizontal stress (Brudy and Zoback, 1999; Lund and Zoback, 1999; Vernik and Zoback, 1992; Zajac and Stock, 1997). The measurement of breakout comes at a small incremental cost associated with the interpretation of the data when compared with traditional testing methods such as CSIRO HI-Cell and Acoustic Emission. As a result of the high cost associated with traditional testing methods, in situ stress data sets are typically small.

In this study, the examination of the in situ stress condition is part of the geotechnical investigation for the open pit slope designs. Stress is one of the inputs for deformation modelling of the pit slopes, which in some areas interact with existing underground infrastructure such as shafts and stopes.

This paper presents a summary of the geological setting of the Olympic Dam deposit, an overview of breakout theory and the results of this study. Comparisons with existing stress data for both the site and region indicates that borehole breakout provides an opportunity to increase the understanding of in situ stress regimes for little additional cost. 


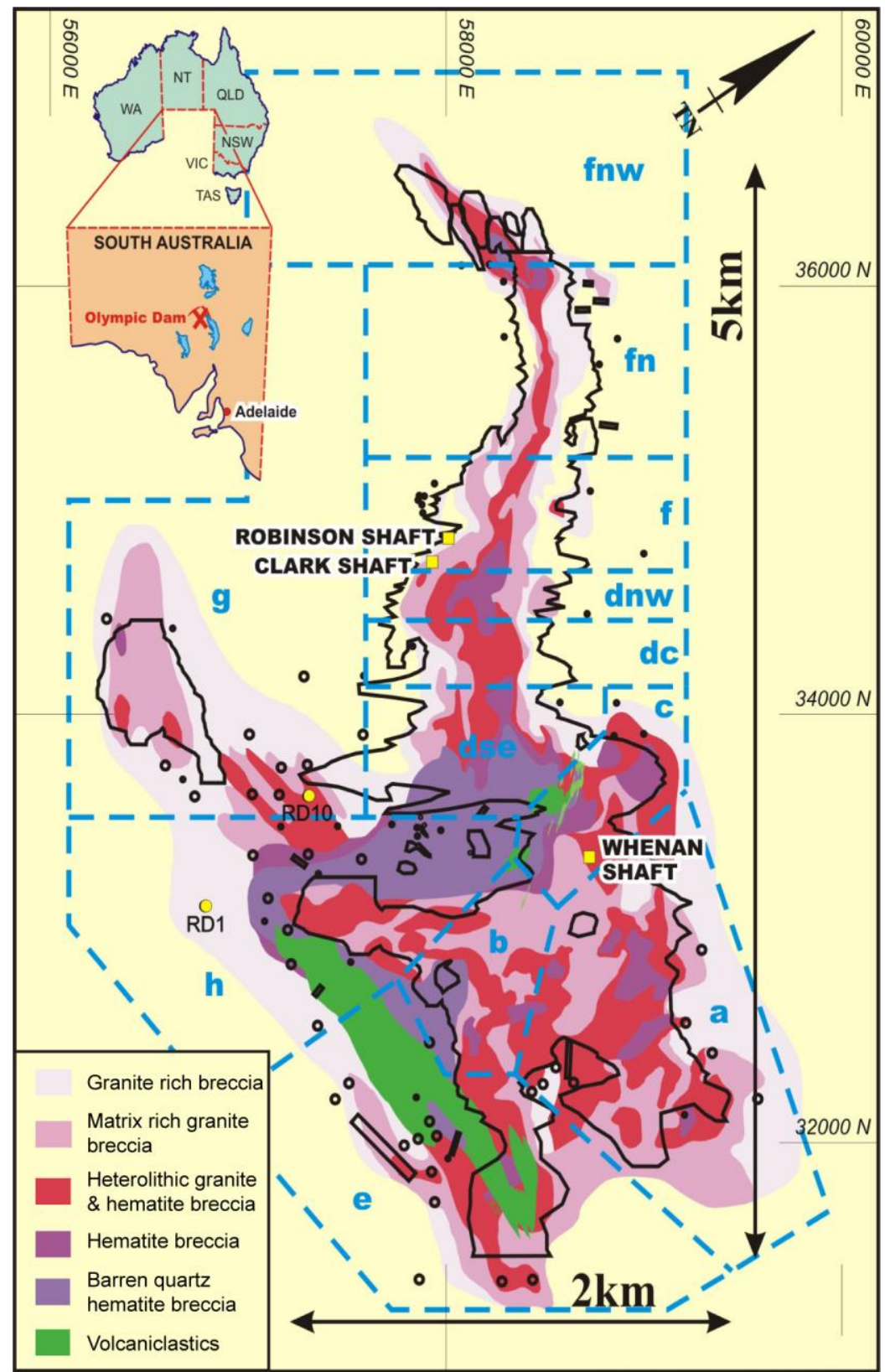

\section{Figure 1 Olympic Dam location and principal lithologies}

\section{Geological setting}

The Olympic dam orebody comprises a highly variable magmatic-hydrothermal breccia complex that displays multiple brecciation, diatreme intrusions, mafic and ultramafic dyke intrusions along with an interpreted gravity collapse of high level volcanic edifice material (Figure 1). The deposit is considered to be a member of the Iron Oxide Copper Gold (IOCG) family of deposits and has a close temporal and spatial association with the Hiltaba Suite of granites, dated at $1590 \mathrm{Ma}$ (early Proterozoic) and more specifically the more fractionated and oxidised Roxby Downs subsuite (1588 Ma).

The main lithologies at Olympic Dam comprise a continuum of breccias, starting at the periphery with granite clasts set in minor haematite matrix continuing to haematite clasts in a haematite matrix. The principal gangue minerals are haematite, sericite and quartz. Minor gangue minerals include; siderite, chlorite, fluorite and barite (Reynolds, 2001).

The orebody and its host rock are overlain by approximately $300 \mathrm{~m}$ of horizontally bedded sedimentary rocks. These rocks are predominately of Late Proterozoic age and comprise quartzite, shales and minor basal 
conglomerates. Overlying this is a thin limestone and shale of Cambrian and Ordovician age, respectively (Reynolds, 2001).

A major structural lineament that crosses the deposit is locally called Mashers fault zone, however, regionally it is known as the Jubilee Fault. This $100 \mathrm{~m}$ wide structural zone comprises a series of sub vertical fault planes that penetrate both the cover sequence and the basement.

\section{Borehole breakout theory}

Borehole breakout is the stress-induced deformation of a borehole cross section in a preferential direction, which occurs when the stress concentration around the borehole exceeds the rock strength (Ask et al., 2006; Babcock, 1978; Bell and Goug, 1979; Zoback et al., 1985). Breakout is a form of compressive failure, with borehole spalling in the direction of minimum horizontal stress (Figure 2). Maximum principal stress orientations from breakout have been shown to be consistent with the results of other more traditional stress measurement techniques such as hydraulic fracturing and overcoring (e.g. Zoback and Zoback, 1980; Plumb and Hickman, 1985; Zajac and Stock, 1997). Breakout length can vary from less than a metre to several tens of metres (Ask et al., 2006).

Breakout is formed by the spalling of fragments from the borehole wall in the direction of minimum horizontal stress $\left(\mathrm{S}_{\mathrm{h}}\right)$, as shown in Figure 2. The specific breakout failure mechanism varies with rock strength, depth and stress state (Plumb, 1989). Within crystalline rocks breakout is initially observed as small pits or irregular chips at the borehole wall, while within sedimentary rocks it first appears as well developed fracture zones (Plumb, 1989; Martin, 1997). Thus, breakout in crystalline rocks is thought to initiate at the borehole wall, compared to initiation within the formation for sedimentary rocks.

A

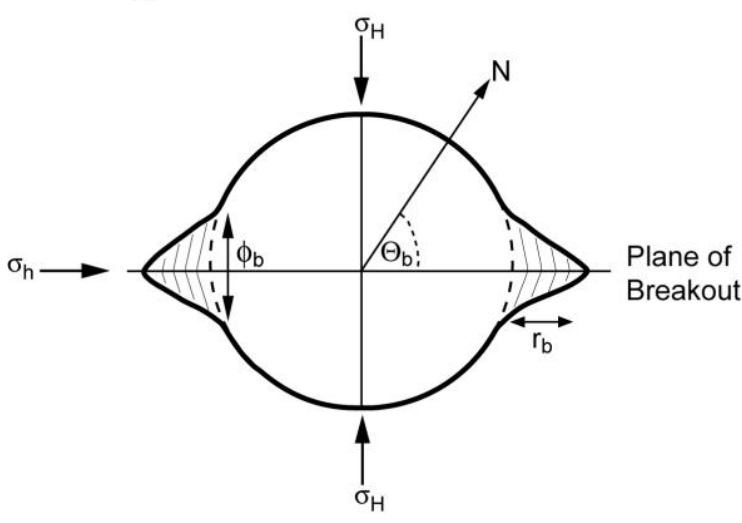

B

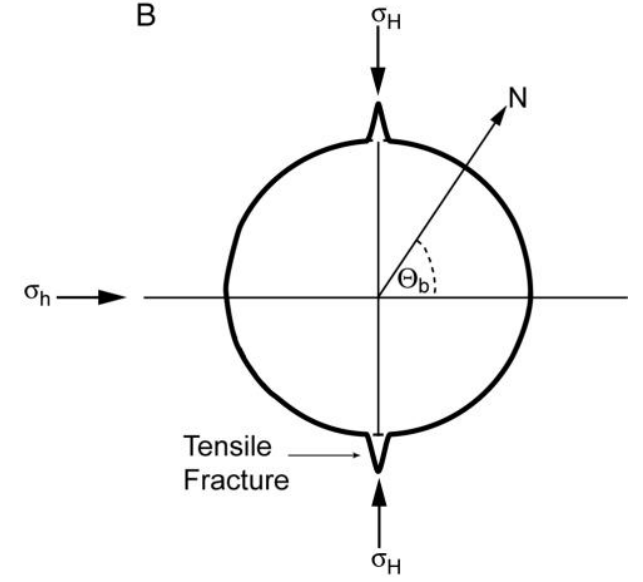

Figure 2 Theoretical borehole cross-section, showing the relationship between the major principal horizontal stress $\left(\sigma_{H}\right)$, the minor principal horizontal stress $\left(\sigma_{h}\right)$ for $(A)$ borehole breakout and $(B)$ tensile fracture. Also defined are the breakout azimuth $\left(\Theta_{b}\right)$, width $(\mathrm{deg})\left(\Phi_{\mathrm{b}}\right)$ and maximum depth $(\mathbf{m m})\left(\mathbf{r}_{\mathbf{b}}\right)$

As shown in Figure 2, the less frequent tensile fractures (TF) are small-scale $(0.1-2 \mathrm{~m}$ length) fractures in the borehole wall in the orientation of maximum horizontal stress (e.g. Brudy and Zoback, 1993; Brudy and Zoback, 1999). The development of TFs is primarily dependent on the stress field perpendicular to the borehole axis, the applied cooling water pressure and temperature, and on the rock type characteristics (Ask et al., 2006). TF have also been observed in sections containing natural fractures and are thought to initiate on small flaws in the borehole wall where no tensile strength has to be overcome (Brudy and Zoback, 1999). TFs have been principally observed in strike-slip (highly deviatoric) regimes due to the appreciable difference in the magnitudes of the maximum and minimum horizontal stresses. These fractures do not appear to propagate significantly into the surrounding rock mass and seem limited to the borehole wall (Brudy and Zoback, 1999). 
The fracture traces for both breakout and TF are easily detected using geophysical imaging tools such as the acoustic televiewer (ATV). Failure occurs parallel to the borehole axis, offset by $180^{\circ}$ and not interconnected around the borehole wall (Brudy and Zoback, 1999).

\section{Results}

\subsection{Measurement of breakout}

The measurement of borehole breakout was undertaken using WellCAD® software version 4.1. A customised template was developed for the project (Figure 3), which presents a log of lithology, field estimated strength, ATV amplitude and travel time (both form an unwrapped pseudo image of the borehole wall), composite borehole cross section, average borehole cross section, a histogram of breakout azimuth, a histogram of breakout width and a histogram of maximum breakout depth. The log shown in Figure 3 is of borehole RD2650 and presents breakout occurring in the Hematite Granite Breccia. The breakout can be seen in the amplitude $\log$ as the two $180^{\circ}$ apposed dark traces parallel to the borehole wall. The measurements of breakout presented in the log are made whilst in the 3D Log mode in the WellCAD software (Figure 3, insets A and B).
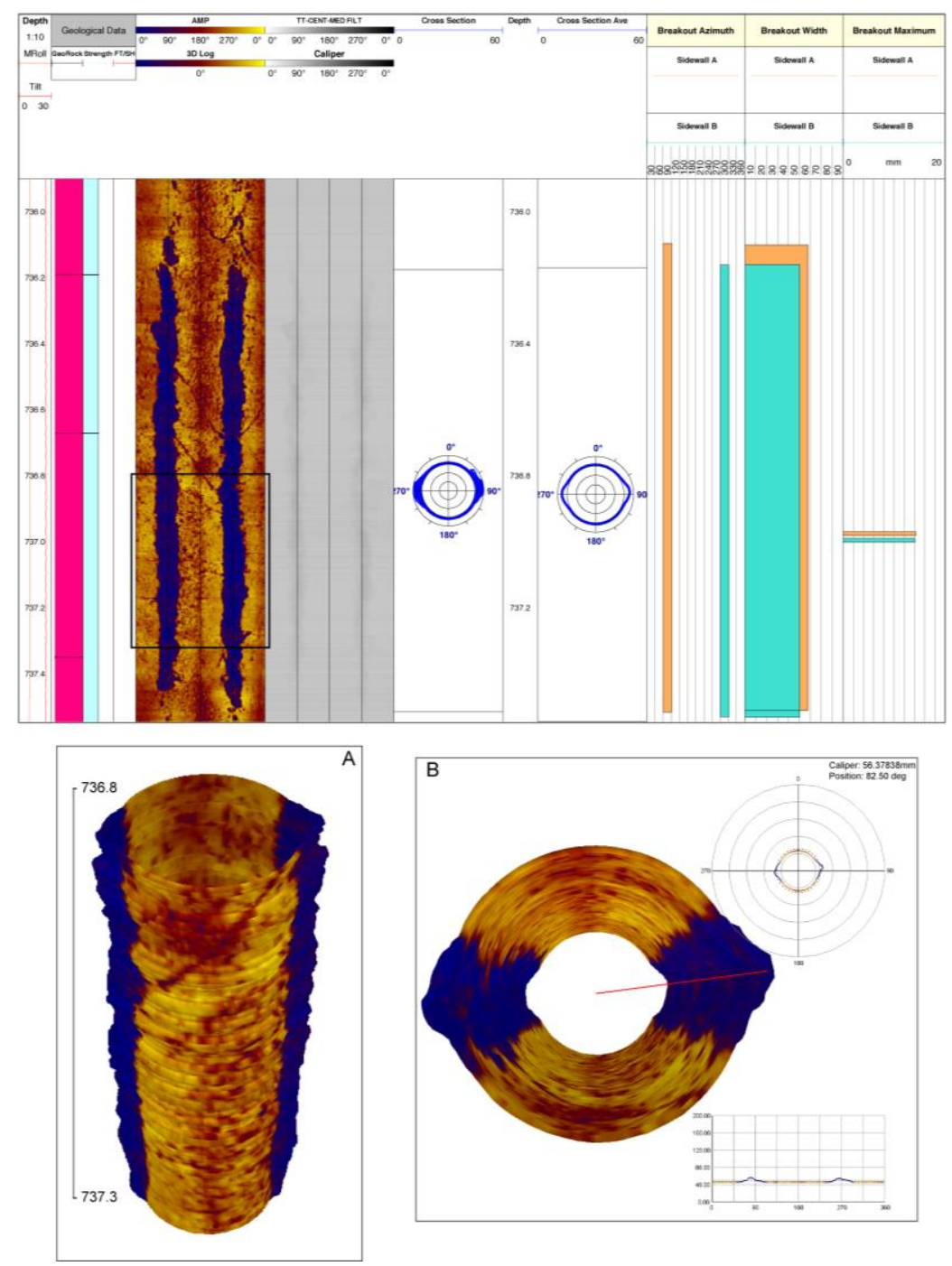

Figure 3 Example of borehole breakout in an acoustic televiewer log. Inset $A$ is a 3D image of the borehole while inset $B$ is a cross-section from the top of $A$ 


\subsection{Borehole breakout}

Acoustic televiewer data has been collected from approximately 500 boreholes across the Olympic Dam site. The depth of drilling where ATV was applied ranges between 57 and $1220 \mathrm{~m}$. From the 500 holes, 96 were selected for borehole breakout assessment. These boreholes provide reasonable coverage of the area of interest for the assessment of stress (Figure 4). From the 96 holes, 154 instances of breakout were observed in 38 of the boreholes. Borehole breakout was observed over a wide range of depths, with a peak in the distribution at 400 to $650 \mathrm{~m}$ below surface.

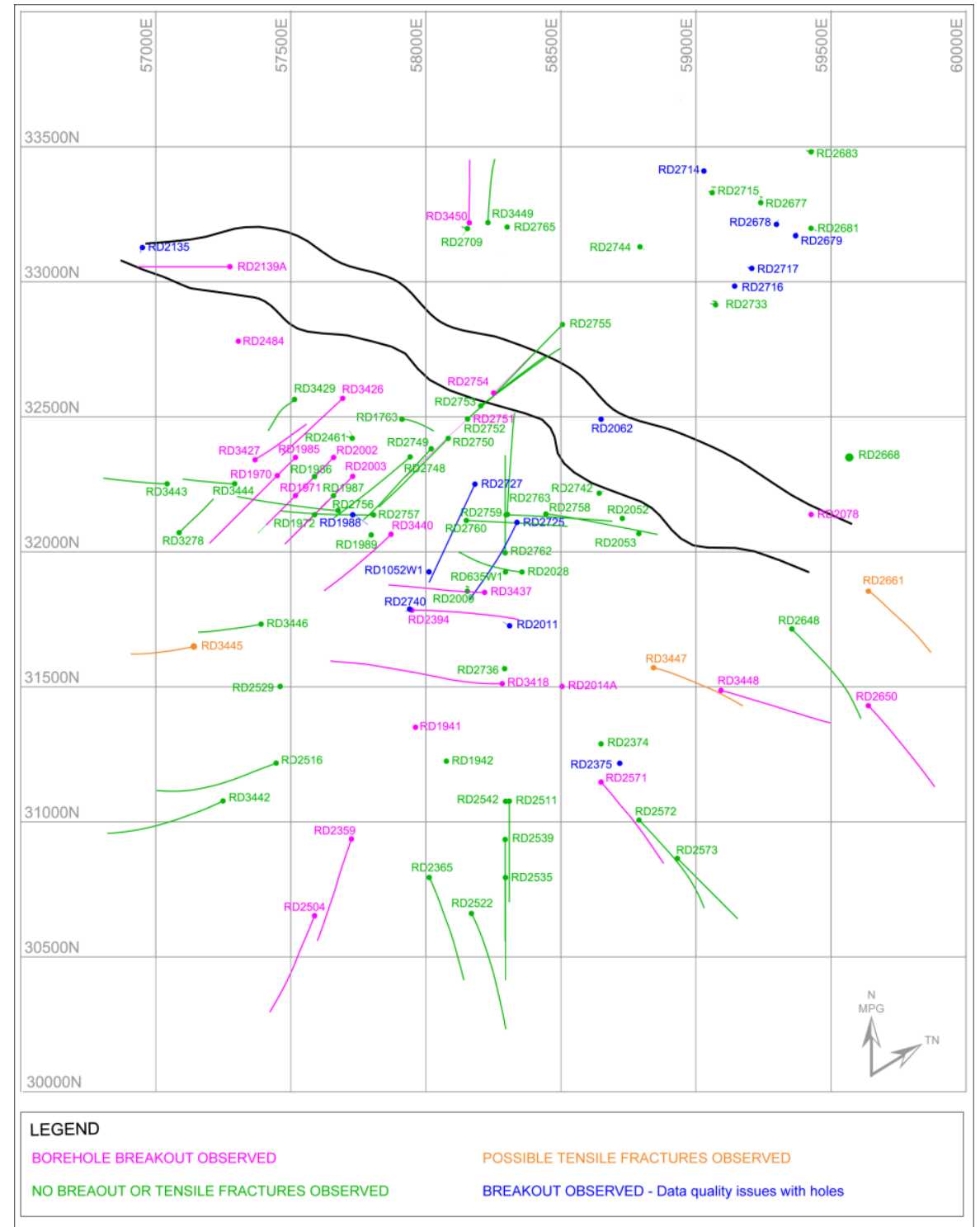

Figure 4 Boreholes investigated for compression and tensile stress fractures

Of the 38 boreholes with breakout, 24 had acceptable data quality for measurement of breakout geometry parameters. The remaining 14 holes were taken from older ATV data with fundamental data quality issues, which meant that whilst the breakout could be clearly observed, the orientation of the breakout was unreliable. There were 94 individual breakout measurements from the 24 recent boreholes. The number of measurements per borehole ranged between 1 and 19. Average breakout length was $1.64 \mathrm{~m}$, with a minimum and maximum of 0.09 and $14 \mathrm{~m}$ respectively. Where breakout was measured in angled boreholes, the orientation of the maximum principal stress (Sigma 1) was assumed to be perpendicular to the borehole breakout projected onto the horizontal plane. 


\subsubsection{Breakout in basement}

There were 147 observations (including those from the older ATV data) of borehole breakout in basement lithologies. There are a high number of breakouts that occur in the granite or hematite dominated breccias. In particular, $45 \%$ of the observations occurred within the GRNH, a granite breccia containing $70-90 \%$ granite and $10-30 \%$ Hematite. This correlation with lithology is most likely the result of drill density rather than a stress related phenomena.

Individual breakouts from three boreholes (RD2014A, RD2484 and RD3448) were interpreted to be effected by unidentified local perturbations and were culled from the overall assessment of Sigma 1. In all three, boreholes breakouts from different depths were used in this assessment.

\subsubsection{Breakout in cover sequence}

Only two of the 38 boreholes (RD2754 and RD2725) had breakouts in the cover sequence. There are a total of nine breakout observations from these two holes, with breakout confined to the Corroberra Sandstone in or around the Mashers fault zone. RD2725 suffered from poor quality orientation data and the data is not presented here.

\subsection{Tensile fractures}

From the 96 boreholes with ATV data that were examined in detail, three locations were identified where wall failure was perpendicular to the general breakout orientation. These fractures were associated with structures within the borehole and the geometry of the failure was subtle. These observations could either be caused by local reorientation of the stress field associated with structures or tensile fractures. It is unclear which of these options is correct, however the authors favour the later.

There were four down borehole measurements from the three holes with possible TFs, shown in Figure 4. The two TFs in borehole RD2661 are located at 210.7 and $211.2 \mathrm{~m}$ below surface, in the Corroberra Sandstone. The remaining two TFs are located in boreholes RD3445 and RD3447 at 402.2 and $775.3 \mathrm{~m}$ below the surface, respectively. These fractures are both located in the Granite breccia. These tensile fractures are much closer to the surface than those in the study of Brudy and Zoback (1999) where the minimum depth was $1400 \mathrm{~m}$ down the borehole.

The average tensile fracture length was $0.61 \mathrm{~m}$, with a range of 1.12 to $0.15 \mathrm{~m}$. This range is similar to the range of 0.1 to $2 \mathrm{~m}$ from Brudy and Zoback (1999). The orientation of the maximum principal stress (Sigma 1) was assumed to be parallel to the tensile fracture projected onto the horizontal plane. The Sigma 1 orientation from RD3445 and RD3447 has an average bearing of $319^{\circ}$, compared to $003^{\circ}$ for RD2661. This $44^{\circ}$ difference in Sigma 1 orientation is attributed to the proximity of RD2661 to the Mashers fault zone.

\section{Comparison with existing data}

Measurements of the stress field at Olympic Dam have previously taken place in the northern part of the ore body associated with underground mining. The underground database consists of:

- 14 CSIRO HI-Cell measurements, 13 in the basement and one in the Tregolana Shale (AMC, 2007).

- Five Acoustic Emission (AE) measurements, four in the basement and one in the Corroberra Sandstone (Villaescusa et al., 2005).

A comparison of Sigma 1 orientations for both data sets is presented in Figures 5 and 6. The direction of major principal stress from the HI-Cell measurements is generally oriented northwest - south east but appears to be rotate sympathetically with changes in the overall strike of mineralisation (Figure 6). The estimated mean bearing and plunge for the major principal stress in the northern mining area (NMA) is $133^{\circ}$ MPG. In the southern part of the deposit the results from the borehole breakout and tensile fractures exhibit a relatively consistent NW-SE orientation, with an average bearing of $140^{\circ} \mathrm{MPG}$. The major principal stress orientation for the southern mining area (SMA) largely appears to fit the existing data for NMA (Figure 6). 
A

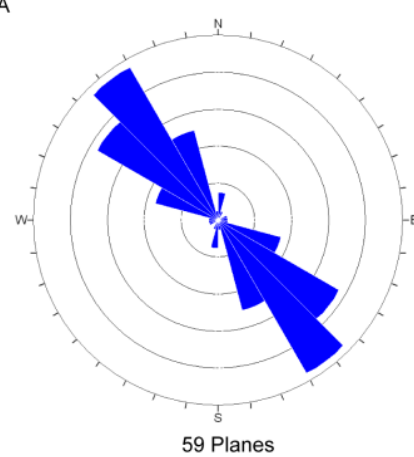

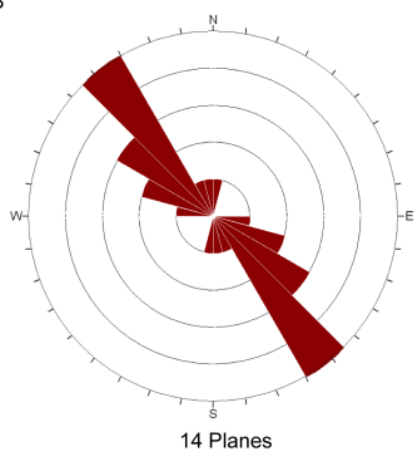

Figure 5 Sigma 1 orientation for the A. Borehole breakout and B. HI Cell. (Bin angle of $15^{\circ}$, number of planes per circle increment is 4 and 1 for $A$ and $B$ respectively)

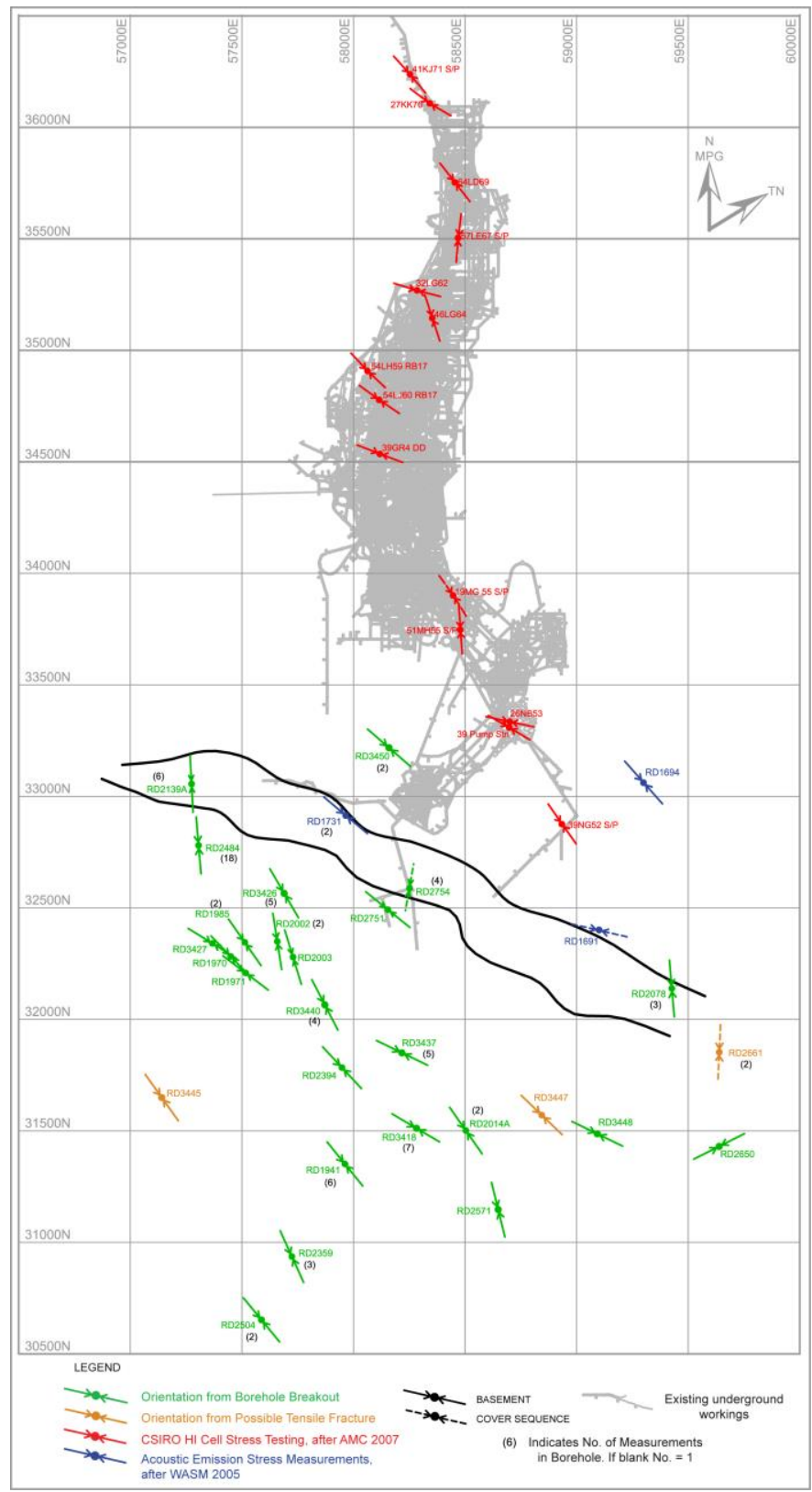

Figure 6 Stress measurements at Olympic Dam 
Plate-boundary forces are thought to exhibit a first-order control on the regional pattern of stress orientation in the Australian Plate, while second-order controls such as structures and topography have been shown to cause locally anomalous stress orientations (Hillis and Reynolds, 2003). The overall trend of the principal stress orientation at Olympic Dam is presented on the Australian stress map and indicates a reasonable comparison with other proximal measurements (Figure 7). There are a number of instances in this data set where the second order effects are evident. For example, boreholes RD2139A, RD2078 and RD2661 exhibit a more North - South principal stress orientation, associated with Mashers fault zone (Figure 6). Also, the principal stress orientation interpreted in borehole RD2650 has a bearing of $063^{\circ}$ MPG for the major principal stress, which is perpendicular to the general trend. This result occurs $0.8 \mathrm{~m}$ below a significant shear, which suggests it has caused a local variation in stress condition.

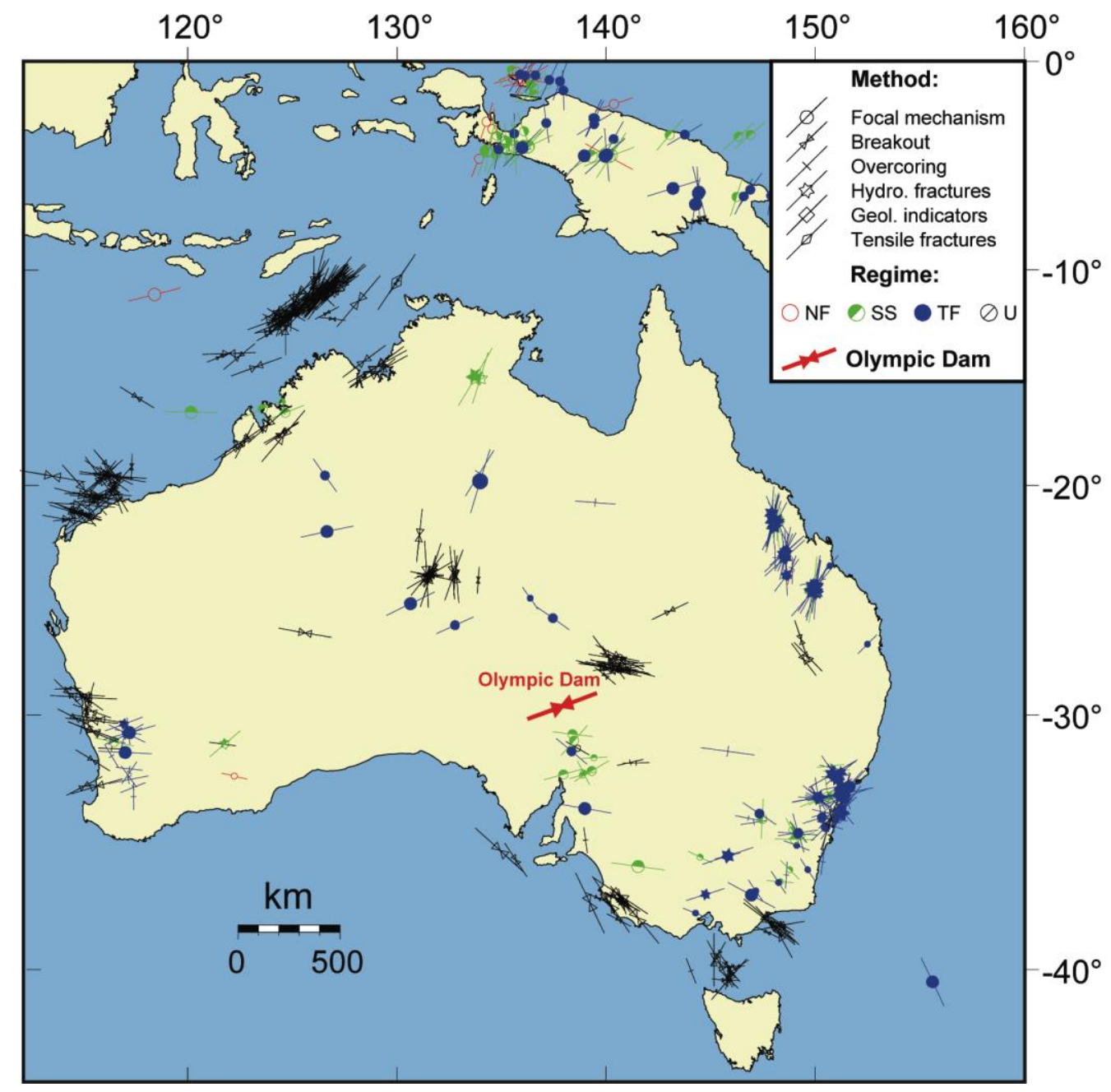

\section{Figure 7 Orientation of major principal horizontal stress at Olympic Dam (red) compared to the Australian Stress Map (after Reynolds, 2008)}

Borehole breakout and tensile fractures have previously been documented at similar depth intervals of the same borehole (e.g. Brudy and Zoback, 1999). However, in this study the two failure mechanisms were found to be mutually exclusive.

Breakout width is controlled by the relative magnitudes of the principal stresses, so that if both the rock strength and one of the principal stresses is known, the magnitude of the remaining principal horizontal stresses can be calculated (e.g. Moos and Zoback, 1990; Vernick and Zoback, 1992; Zajac and Stock, 1997). The dataset from this study provides a unique opportunity to compare the breakout stress magnitudes with the existing overcoring measurements and is an area for further investigation. 


\section{Conclusions}

The use of borehole breakout identified from acoustic borehole images provides a reliable measure of the principle stress direction. Specific conclusions about the Olympic Dam site include:

- The orientations of the principle horizontal stress, based on the breakout method, are in good agreement with both the overall trend of traditional measurements at Olympic Dam and other regional orientations.

- Excluding data in the mashers fault zone, the breakout data appears to have slightly less variation than the traditional measurements associated with the underground works. This could either be the result of stress effects from nearby workings or alternatively because of real variations in stress associated with the geometry of the ore body in this area.

- There is a relatively consistent principle stress orientation of $140^{\circ} \mathrm{MPG}$ in the basement rocks south of mashers fault.

- Breakouts measured in close vicinity or within mashers fault zone suggest a local stress perturbation oriented north - south.

- There is insufficient data to confirm whether the cover sequence has a similar stress orientation as the basement.

The following general conclusions can be made based on this study:

- The use of breakout measurements is a reliable way to identify the principle stress orientation, provided the mode of failure is accurately identified.

- Borehole breakout can be used to augment existing data sets. The augmentation may reduce the number of traditional tests or alternatively provide confidence about the continuity of stress between conventional measurements.

- The emerging trend of closely spaced acoustically logged borehole data provides an opportunity to understand the stress regime in greater detail at little additional cost.

\section{Acknowledgements}

The authors would like to thank the many people from the Olympic Dam mine site who have been involved in the field work and data collation. Thanks also to Gareth Swarbrick of Pells Sullivan Meynink for technical assistance.

\section{References}

AMC Consultants Pty Ltd (2007) Re-interpretation of the in situ stress field and its relationship with geologic structures at the Olymic Dam Mine. AMC Project 106113, 302 p.

Ask, M.V.S., Ask, D. and Christiansson, R. (2006) Detection of borehole breakouts at Forsmark site, Sweden. In-situ Rock Stress - Measurement, Interpretation and Application, Lu, Li, Kjøholt and Dhale (editors), Taylor \& Francis, London, pp. 79-86.

Babcock, E.A. (1978) Measurement of subsurface fractures from dipmeter logs: AAPG Bulletin, 62(7), pp. 111-1126. Reprinted 1990 in Foster, N.H. and Beaumont, E.A. (editors) Formation evaluation II - log interpretation: AAPG Treatise of Petroleum Geology Reprint Series 17, pp. 457-472.

Bell, J.S. and Gough, D.I. (1979) Northeast-southwest compressive stress in Alberta: Evidence from oil wells. Earth and Planetary Science Letters 45(2), pp. 475-482.

Brudy, M. and Zoback, M.D. (1993) Compressive and tensile failure of boreholes arbitrarily-inclined to principal stress axes: application to the KTB boreholes, Germany. International Journal OF Rock Mechanics and Mining Sciences Geomechanics Abstracts 30, pp. 1035-1038.

Brudy, M. and Zoback, M.D. (1999) Drilling-induced tensile wall-fractures: implications for determination of in-situ stress orientation and magnitude. International Journal of Rock Mechanics and Mining Sciences 36, pp. 191-215.

Hillis, R.R. and Reynolds, S.D. (2003) In situ stress field of Australia. Evolution and Dynamics of the Australian Plate, R.R. Hillis and R.D. Múller (editors), Geological Society of Australia Special Publication 22, pp. 43-52. 
Lund, B. and Zoback, M.D. (1999) Orientation and magnitude of in situ stress to $6.5 \mathrm{~km}$ depth in the Baltic Shield. International Journal of Rock Mechanics and Mining Sciences 36, pp. 169-190.

Martin, C.D. (1997) Seventeenth Canadian Geotechnical Colloqium: The effect of cohesion loss and stress path on brittle rock strength, Canadian Geotechnical Journal 34(5), pp. 698-725.

Moos, D. and Zoback, M.D. (1990) Utilization of observations of well bore failure to constrain the orientation and magnitude of crustal stresses: Application to continental, Deep Sea Drilling Project and Ocean Drilling Project boreholes. Journal of Geophysical Research 95(B6), pp. 9305-9325.

Plumb, R.A. (1989) Fracture patterns associated with incipient borehole breakouts. Rock at Great Depth, V. Maury and D. Fourmaintaux (editors), 2, Balkema, Rotterdam, pp. 761-768.

Plumb, R.A. and Hickman, S.H. (1985) Stress-induced borehole elongation: A comparison between the four-arm dipmeter and the borehole televiewer in the Auburn Geothermal well. Journal of Geophysical Research 90(B7), pp. 5513-5522.

Reynolds L.J. (2001) Geology of eth Olympic Dam Cu-U-Au-Ag-REE Deposit. Mesa Journal 23, October 2001, pp. $37-44$.

Reynolds, S. (2008) Stress Maps, Australian School of Petroleum, Adelaide University. Available from: <http://www.asprg.adelaide.edu.au/asm/maps.html> [accessed 5th April 2008]

Vernick, L. and Zoback, M.D. (1992) Estimation of maximum horizontal principal stress magnitude from stressinduced well bore breakouts in the Cajon Pass Scientific Research Borehole. Journal of Geophysical Research 97(B4), pp. 5109-5119.

Villaescusa, E., Li, J. and Windsor, C. (2005) Stress measurements from oriented core using the Acoustic Emission Method. Western Australian School of Mines, Curtin University of Technology Report for WMC Resources Limited, Olympic Dam Operations Southern Resource, unpublished.

Zajac, B.J. and Stock, J.M. (1997) Using borehole breakouts to constrain the complete stress tensor: Results from the Sijan Deep Drilling Project and offshore Santa Maria Basin, California. Journal of Geophysical Research 102(B5), pp. 10083-10100.

Zoback, M.L. and Zoback, M.D. (1980) State of stress in the conterminous United States. Journal of Geophysical Research 85(B11), pp. 6113-6156.

Zoback, M.D., Moos, D., Mastin, L. and Anderson, R.N. (1985) Well bore breakouts and in situ stress. Journal of Geophysical Research 90, pp. 5523-5530. 